\title{
Analysis of Theodicy Concepts and Its Relevance during the COVID-19 Pandemic Period
}

\author{
Martin Elvis ${ }^{1)^{*}}$, Daniel Ronda ${ }^{2)}$ \\ 1) Theology Department, Sekolah Tinggi Teologi Cipanas, Indonesia \\ 2) Theology Department, Sekolah Tinggi Filsafat Theologia Jaffray Makassar, Indonesia \\ *) Correspondent author:martin.elvis@me.com
}

Received: 18 December 2020/ Accepted: 26 March 2021/ Published: 01 April 2021

\begin{abstract}
The COVID-19 pandemic problem raises many questions, whether the pandemic exists because of human sin? Is this suffering from God? Does God allow this to happen? If God is love, why should this pandemic occur? And various other kinds of questions. The purpose of this study is to find relevant values of theodicy concepts during the COVID-19 pandemic. This method uses qualitative research methods on the seven selected theodicy concepts and the latest research journals' results. Comprehensive results are obtained from the seven angles view of theodicy concepts relevant during the COVID-19 pandemic. From the study results, it can be concluded that the values of each theodicy concept studied gave appropriate contributions during the COVID-19 pandemic.
\end{abstract}

Keywords: COVID-19, pandemic, sin, suffering, theodicy

\begin{abstract}
Abstrak
Masalah pandemi COVID-19 menimbulkan banyak pertanyaan, apakah pandemi itu ada karena dosa manusia? Apakah penderitaan ini dari Allah? Apakah Allah mengizinkan hal ini terjadi? Jika Allah itu kasih mengapa pandemi ini harus terjadi? Dan pelbagai macam pertanyaan lainnya. Tujuan penelitian ini adalah menemukan nilai-nilai yang relevan dari konsep teodise pada masa pandemi COVID-19, dengan menggunakan metode penelitian kualitatif terhadap tujuh konsep teodise terpilih, dan hasil penelitian jurnaljurnal terkini, sehingga didapatkan hasil yang komprehensif dari ketujuh sudut pandang konsep teodise yang relevan pada masa pandemi COVID-19. Dari hasil penelitian dapat disimpulkan bahwa nilai-nilai dari setiap konsep teodise yang diteliti memberikan sumbangsih yang relevan pada masa pandemi COVID-19 ini.
\end{abstract}

Kata-kata Kunci: COVID-19, dosa, pandemi, penderitaan, teodise 


\section{Introduction}

The problem of suffering is a problem that humans always face in this world. The current context of suffering worldwide is facing a coronavirus pandemic, later called COVID-19. The spread of the virus was so fast that it has spread to 216 countries with $14,971,036$ positive cases of contracting COVID-19 and has claimed 618,017 lives at the time of writing. ${ }^{.}$This pandemic virus problem then raises the question for everyone: why did this happen? Did God send this virus? Does God not help when humans suffer and die from this virus? Where is God's justice? Where is God's goodness? And various other questions.

In the world of theology, there is a term called theodicy, which is an attempt to solve the problem of evil that is to align the existence of an all-forgiving, omnipotent and omniscient God with the presence of evil or suffering in this world. How could an almighty and good God allow suffering in this world? Various theologians throughout the ages allude to the problem of suffering. They have their respective theological views.

\section{Theory}

The author's theoretical study is based on a literature review and research results from the latest journals to support the author's thesis, limiting the seven selected theological concepts of theodicy and seeing whether they are relevant in the context of the COVID-19 pandemic.

\section{Definition of Theodicy}

Theodicy comes from the Greek words "theos" (God) and "dike" (justice), translated to "divine justice." Efforts to defend the omnipotence and goodness of God in dealing with evil problems in the world. ${ }^{2}$ Theodicy is also interpreted as a theological problem of trying to reconcile suffering and evil in the created world with the idea of a good

\footnotetext{
${ }^{1}$ Q\&EA on coronaviruses (COVID-19). World Health Organization, pp. 1-2. Retrieved July 23, 2020, from https://www.who.int/emergencies/diseases/novelcoronavirus-2019/question-and-answers-hub/q-a-detail/q-a-coronaviruses.

${ }^{2}$ Brooks, P., \& Neal, D. A., The Lexham Bible Dictionary (J. D. Barry, D. Bomar, D. R. Brown, D. Klippenstein, D. Mangum, \& C. Sinclair Wolcott, Eds.) (Bellingham, WA: Lexham Press, 2016).
} 
and loving God. ${ }^{3}$ According to Scott, the technical term the theodicy signifies the defence of divine justice in the face of evil. It uses a logical strategy to "justify God's ways for humans," that is, to justify God from moral error. More broadly, theodicy shows efforts to explain or understand suffering. ${ }^{4}$ Leibniz is known as the first author of the term theodicy. In 1710, one of his most significant theological works was Essais de Théodicée sur la bonté de Dieu, la liberté de l'homme et l'origine du mal. In 1714 he wrote Monadologie (pub. 1720) and Principles de la nature et de la grâce (pub. 1718), which, although brief, contained the only systematic record of his metaphysical doctrine. Throughout his life, Leibniz diligently devoted himself to the goal of international peace. ${ }^{5}$ Since their first appearance in 1710, Leibniz's Essais de théodicée quickly became one of the most influential and brilliant early modern philosophies. Pretty famous job. However, after three centuries of controversy and debate, this work still needs scrutiny and clarification. Although the main principle of Leibniz's justification of God's goodness is familiar to every scholar, the argument Leibniz uses for that purpose, as well as his historical and conceptual background, is by no means general knowledge. The philosophical depth of theodicy doctrine is not always easy to appreciate. ${ }^{6}$

\section{Various Types of Theodicy}

Gottfried Wilhelm Leibniz's Theodicy

Early modern philosopher Gottfried Wilhelm Leibniz (1646-1716) said the world that exists is the best world created by God. Leibniz's argument for the best doctrine of all possible worlds, now commonly called Leibnizian optimism, is presented in its most complete form in the work of Théodicée, which is devoted to defending God's justice. Thus, the argument is Leibniz's solution to evil or the apparent contradiction

\footnotetext{
${ }^{3}$ Mangum, D. The Lexham Glossary of Theology (Bellingham, WA: Lexham Press, 2014).

4 Scott, M. S. M. Pathways in Theodicy: An Introduction to the Problem of Evil. (Minneapolis: Fortress, 2015), 56.

${ }^{5}$ F. L. Cross and E. A. Livingstone, eds., The Oxford Dictionary of the Christian Church, The Oxford Dictionary of the Christian Church (Oxford University Press, 2009), https://www.oxfordreference.com/view/10.1093/acref/9780192802903.001.0001/acref9780192802903.

${ }^{6}$ Camposampiero, M. F., Geretto, M., \& Perissinotto, L. Theodicy and Reason Logic, Metaphysics, and Theology in Leibniz's Essais de Theodicee (1710), (Venesia: Digital Publishing, 2016), 9 .
} 
between the assumption. That God is omnipotent, omniscient, and supreme (excellent) and the real fact of evil (including sin and suffering that is not appropriate) in the world. ${ }^{7}$ Leibniz divides crime into three parts: metaphysical, physical, and moral. Metaphysical crime consists solely of imperfection, physical evil in suffering, and moral evil in sin. ${ }^{8}$

\section{Dietrich Bonhoeffer's Theodicy}

Early in his theological development, Bonhoeffer explained that he was not interested in formulating a logical explanation of theodicy. And for him, there is no way to solve the theodizing problem on philosophical grounds. Following Luther, Bonhoeffer realized that philosophy could not provide a rational solution to the problem of evil. The answer is not found in humans or logical explanation; it must be found elsewhere. Bonhoeffer remains true to this essential commitment. ${ }^{9}$

\section{Augustine's Theodicy}

Augustine struggled with the question of evil throughout his life. His doctrine of God resolutely affirms two basic premises: First, that God is Almighty God who can do anything that He wants to the extent that such actions are consistent with His existence, and secondly, that God is a good God and therefore not a direct cause of any crime. Because of this, his doctrine of creation states that God created ex nihilo (from nothing) and therefore sovereign over all things, and He created all things the good because He is a good God. ${ }^{10}$

\section{Irendean's Theodicy}

Irenaeus (130-202 AD), the famous church father, said that God allows evil and suffering in this world to his creation's moral advantage. The theodicy is also called the "soul-making" theodicy. God did not create evil but allow evil for the benefit of humanity. Humans have the

7 T. Editors of Encyclopaedia Britannica, "Best of all possible worlds," Encyclopedia Britannica, June 6, 2017, https://www.britannica.com/topic/best-of-allpossible-worlds.

${ }^{8}$ Leibniz, F. von G. W. THEODICY: Essays on the Goodness of God, the Freedom of Man, and the Origin of Evil (Austin Farrer, Ed.). BiblioBazaar. (Oxford: Bibliobazaar, 2007), 139.

${ }^{9}$ A. Aubert, "Theodicy and the Cross in the Theology of Dietrich Bonhoeffer," Trinity Journal 32, no. 1 (2011): 55.

${ }^{10}$ N. Vorster, "The Augustinian Type of Theodicy: Is It Outdated?" Journal of Reformed Theology 5, no. 1 (2011): 27, https://doi.org/10.1163/1569731l1X562201. 
moral ability to choose between good and evil without coercion or outside influence. Knowledge about crime and suffering can be helping humanity to know what is right. In this world, even such heinous actions, murder, theft, and war, are needed for humanity's progressive moral. God allows for possibilities of evil and suffering in this world for the "soul-making" of humans to achieve moral maturity."

\section{John Hick's Theodicy}

After seven years of teaching in America, Hick returned to England in 1963 and became a religious philosophy lecturer at Cambridge University. Here, he developed his current Irenaean theodicy famous (influenced by the early church father, Irenaeus), and publishing what is widely considered to be one of the works definitive about the problem of crime, Evil and the God of Love. ${ }^{12}$ Hick interprets life's sufferings as part of where people's soul-making journey is perfected from time to time. He refused the model Augustinian, who looks back to the time when humans fell from grace and thus bring evil to the world; instead, he sees evil as part of the divine intention to shape the soul to be like God (similitudo dei). This is an excellent result that will be experienced by all (universalism).$^{13}$ Hick offers a determination of free will with which freedom is the goodness of character virtuous formed through free actions. Producing the virtues made can only be achieved with God's permission for evil natural. God is reasonable in allowing natural evil to occur in the world because allowing them is necessary for this freedom to achieve well. ${ }^{14}$

\section{Calvin's Theodicy}

Miller, in his research findings, concluded: Two main themes emerged from Calvin's theory. First, as you well know, divine hiddenness plays an important role. As applicable to evil's origin, hiding the divine shows that God is just, but the reasons are behind it His justice remains hidden. Second, the foundation is based on The Scriptures in their

\footnotetext{
${ }^{11}$ J. A. du Rand, "The Mystery in Theodicy," Neotestamentica 50, no. 3 (2016): 171, https://doi.org/10.1353/neo.2016.0023.

${ }^{12}$ Cheetham, David. John Hick: A Critical Introduction and Reflection. Routledge. (New York: Routledge, 2017), 4.

${ }^{13}$ Ibid., 8.

${ }^{14}$ T. R. Byerly, "Free Will Theodicies for Theological Determinists," Sophia 56, no. 2 (2017): 291. https://doi.org/10.1007/sl1841-016-0563-8.
} 
theology. Calvin is not interested in philosophical speculation, also not interested in people's opinions. On the contrary, Calvin surrenders himself entirely to the Word of God - to taught and corrected by it. How did Calvin respond when the two parts of the Bible are contradictory? Instead of stating one part is true, and the other is wrong, Calvin accepts both of them with the same power. When God declared that murder wrong and then asserted that He ordained murder, His son, Calvin, admitted that both were true. How about two seemingly contradictory statements that can be made in harmony might be outside Calvin's understanding, but it's not outside God's reach. ${ }^{15}$

\section{S. Lewis' Theodicy}

In his research on Theodicy in Lewis's writings, McGraw concluded three of five points: First, his theology is a conscious effort to uncover the implications of certain key biblical texts. Specifically, believers must mention Romans 8 and 2 Corinthians 4. Rome 8: 18-19, "For I believe, that the suffering of today cannot be compared with the glory that will be revealed to believers. Because longing for all beings to look forward to God's children stated." In 2 Corinthians 4:17, "For this current mild affliction, work for us eternal glory above all, far more significant than our suffering." Second, Lewis consistently emphasizes that the main solution to pain is faith, not vision. The greatest need is not proof academic but caring for the soul. Third, he understands that truth, goodness, and beauty are divine. They are not only a reminder of transcendence, but they too are an example. In other words, they are more important than pain. The feel of pain will fade away "almost invisible," and believers will partake of the beauty that is longed for. ${ }^{16}$

\section{Context of the COVID-19 Pandemic}

All humanity is facing the context of suffering caused by the spread of COVID-19 throughout the world. The impact caused by the COVID-19 pandemic is comprehensive, including health problems, economic problems, social problems, and education problems. This COVID-19 pandemic caused many people to lose their jobs, famine, and death. In

${ }^{15}$ T. E. Miller, "Reformed Theodicy: Calvin's View of the Problem of Evil," Prj, 10, (2018): 138, http://www.reformed.org/documents/calvin/calvin_predest_3.html.

${ }^{16}$ E. McGraw, "Peace, child; you don't understand: Theodicy in the writings of $C$. S. Lewis," The Westminster Theological Journal 80, no. 1 (2018): 74-75. 
addition to the problems, there are also struggles with spiritual issues and how believers deal with the COVID-19 pandemic. In the conclusion of his research, Louw writes, as a spiritual category, hope is the laughter of the human soul when sadness seems to be the only choice. Laughing as a spiritual category means humour in the Christian faith: "Where, death, your sting?" (1 Cor. 15:55). A humorous laugh of faith is the knowledge and epistemology of hope, namely that the resurrection of Christ conquers death. In this case, the Christian version of hope cannot go beyond the reality of suffering. Compassion, service (diaconal), and hospitality are instruments that accompany hope in finding a way back to the existential reality of human grief, pain, suffering, and non-hope.

Thus, the importance of praxis service is the hope service. ${ }^{17}$ In Christian spirituality and pastoral caregiving, the core question is who God is during the pandemic. Appropriate God-images can promote human well-being. Skewed God-images, as in many theodicy theories, rational (attempts to link and explain God's goodness and love to evil, and human disruption, suffering) contribute to spiritual intoxication (religious pathology). We cannot lockdown God, but we can infect theological reflection and ecclesial paradigms. ${ }^{18}$

\section{Method}

In what follows, we shall examine how three twentieth-century theologians understood the powers of death, particularly the modes by which such powers are manifested in the world, ways that relate to but are irreducible to an individual's life. The three figures of interest here are Karl Barth (a Swiss Reformed theologian), Walter Wink (an American Bible scholar), and William Stringfellow (an American civil rights lawyer).

The essay employs documentary analysis to identify their contributions to the subject and to rehearse their encouragement to those living amid while seeking to expose and resist the powers of death. It argues that while death and its associated powers are pervasive, they

${ }^{17}$ D. J. Louw, ""The aesthetics of Covid-19 within the pandemic of the corona crisis. from loss and grief to silence and simplicity-a philosophical and pastoral approach," Acta theol. 40, no. 2 (2020): 139, http://dx.doi.org/10.18820/23099089/actat.v40i2.08.

${ }^{18}$ Ibid., 126. 
are also penultimate realities. The powers of death meet their end in Jesus Christ. The gospel concerning Jesus Christ is the invitation to live as if such a claim were valid, recognise one for whom death is not foreign territory, and whom death is confronted and its powers brought to nought. It is the invitation to a life in which resistance to the powers of death is possible. It is the invitation to live a life characterised by resurrection. ${ }^{19}$

\section{Result and Discussion}

The author explains there are seven Theodicy Concepts and explains their relevance in the context of the Covid-19 pandemic as the human suffering concept studied gave appropriate contributions during the COVID-19 pandemic.

\section{Irenaeus Theodicy}

Theodicy of Irenaeus describes God as being responsible for evil but justified because it is beneficial for human development. Haig's research conclusions say by basing the need for reconciliation in metaphysics, not in ethics or law, the Father's actions in sacrificing his son can be justified convincingly. The idea of justice, which is more reasonable and not just, and forgiveness is possible compared to criminal substitution theory. This makes participatory views more tenable. The theory naturally lends itself to the broader Irenaean Theodicy. ${ }^{20}$ The Irenaean tradition in theodicy emphasizes the resolution of a crime that continues to grow. Instead of interpreting evil in the world as a fall from what was once perfect conditions, it treats evil as a necessary stage in developing spiritually mature humans from immature conditions. ${ }^{21}$ In other words, humans who have committed crimes are a process of human maturity.

${ }^{19}$ E. McGraw, "Peace, child; you don't understand: Theodicy in the writings of C. S. Lewis," The Westminster Theological Journal 80, no. l (2018): 75.

${ }^{20}$ A. R. Haig, "Dying and Living with Christ: A Sketch of a Participatory Theory of the Atonement Founded in Platonic Realism and an Irenaean 'Soul-Making' Theodicy," Colloquium: The Australian and New Zealand Theological Review 5l, no. 1 (2019): 100, https:/hcommons.org/deposits/item/hc:27869/.

${ }^{21}$ M. L. Peterson, (Ed.). The problem of evil (Second Edi). (Indiana: University of Notre Dame, 2016), 6. 


\section{Augustine Theodicy}

Theodicy of Augustine tried to free God from all responsibility of evil, based on freedom of will. The Augustinian Theodicy supports the view of original sin. Human free will is assumed an act of man committing evil by man's evil will, which has been polluted by sin. The results of Vorster's research say that the Augustinian paradigm can be resolved from within and that there is no need for Reformed theologians to replace the Augustinian paradigm with an alternative paradigm of Ireneaen that rejects the primary teachings of the Bible about creation and $\sin .22$

\section{Calvinist Theodicy}

Silva said, to establish the Calvinist Theodicy, it is first necessary to look at Calvin's view of God, His omnipotence and goodness, and then on the doctrine of divine providence. Because everything in Calvin's theology always begins with the knowledge of God, to develop a theory based on Calvin's writings, believers must start with God and His attributes. ${ }^{23}$ Further said, Calvin believes that believers cannot have a right view of God without discovering that $\mathrm{He}$ is the source of all goodness. Although the term "theodicy" does not yet exist, Calvin's view of God establishes two of the three theological statements: God is omnipotent, and God is good. This is how God the Father is revealed in the Bible and Calvin's theology. Based on Calvin's works, it can be concluded that the first two statements of theodicy are biblical true and interconnected. ${ }^{24}$

\section{G. W. Leibniz Theodicy}

Leibniz generally avoids excessive crimes and exaggerates human suffering like Augustine, Luther, or Pascal's perspective. For Leibniz, even if humans cannot be saved without Christ, that does not mean that pagan virtues are wrong and that all their actions are sinful. Further said, this [moral] evil is not so great in humans, as stated. Only people of evil

22 N. Vorster, "The Augustinian Type of Theodicy: Is It Outdated?" Journal of Reformed Theology 5, no. 1 (2011): 26, https://doi.org/10.1163/156973111X562201.

${ }^{23}$ T. M. Silva, "God and the Meaning of Human Suffering Based on Calvin's Theological Perspective: A Theodicy," Puritan Reformed Journal 7, no. 2 (2015): 82.

${ }^{24}$ Silva, "God and the Meaning of Human Suffering Based on Calvin's Theological Perspective: A Theodicy," 84. 
character or those who have become disadvantaged because of misfortune. ${ }^{25}$

\section{S. Lewis Theodicy}

In his research, McGraw concluded the views of C.S. Lewis are as follows: First, if this is not proven from Lewis's words, then it must be explained that the theodicy is a conscious effort to uncover the implications of certain key biblical texts. Second, Lewis consistently emphasizes that the primary solution to the problem of suffering is faith, not vision. Third, he understands that truth, goodness, and beauty are divine. Not only are they reminders of transcendence, but they are also examples. ${ }^{26}$

\section{Dietrich Bonhoeffer Theodicy}

In his conclusions from his research results, Aubert said Bonhoeffer did not pay attention by giving a rational explanation of crime. Instead, he sought to solve the problem of evil through the theology of Crucis, thus offering "Christological theodicy." Furthermore, it is said that the source of evil must lie in humanity and not in God. ${ }^{27}$

\section{John Hick Theodicy}

John Hick argues that the type of 'Augustinian' Theodicy is based on an outdated world view derived from a literalist understanding of creation's narrative and that it is impersonal and deterministic. Therefore, it needs to be replaced with the 'Irenaean' type of theodicy, whether the article examines its claim by asking whether the 'Augustinian type' theodicy can answer the question of crime postNewtonian world with an evolutionary understanding of reality. ${ }^{28}$

According to Cheetham, Hick revealed the secrets of life's suffering as part of a soul-making journey in which people are perfected from time to time. He rejects the Augustinian model, which looks to humankind's

\footnotetext{
${ }^{25}$ Paul Rateau, Leibniz on the Problem of Evil (New York: Oxford University Press, 2019), 3-4.

${ }^{26}$ E. McGraw, "Peace, child; you don't understand: Theodicy in the writings of C. S. Lewis," The Westminster Theological Journal 80, no. 1 (2018): 74-75.

${ }^{27}$ A. Aubert, "Theodicy and the Cross in the Theology of Dietrich Bonhoeffer," Trinity Journal 32, no. 1 (2011): 65.

${ }^{28}$ N. Vorster, "The Augustinian Type of Theodicy: Is It Outdated?" Journal of Reformed Theology 5, no. 1 (2011): 27, https://doi.org/10.1163/156973111X562201.
} 
time to fall from grace and thus brings evil to the world; instead, he sees evil as part of the divine intention to shape the soul to be like God (similitudo dei). This is a good result without limits that will be experienced by all (universalism). According to Hick, creating souls by God is not complete in worldly existence but continues after death. He theorized that the conditions necessary for soul-making include "epistemic distance" (meaning that the world likes limited thoughts as if there is no God) and that there are real challenges, risks, and temptations (which provide opportunities for free beings to grow in virtue). ${ }^{29}$

The seven concepts of theodicy that have been described above also found differences in views. Even one denounced others' view, such as the view of John Hick, who said Augustinian theodicy had expired. This was also written in Kellenberger's research, which said, Every Theodicy has detractors. Sometimes supporters of one theodicy will be another critic. Those who reject belief in God, the atheists, consider the problem of evil, criticize and reject every theory put forward. Which blatantly gives a reason that God is almighty and wholly good to permit evil. ${ }^{30}$ In his research, Nico said: Although the classic 'Augustinian' type of theodicy is based on an outdated world view, and also contains an inherent tension between the inevitability of $\sin$ and human responsibility. Reformed scholars don't need to replace the Augustinian paradigm with the 'Irenaean type' theodicy. The Augustinian paradigm's weaknesses can be resolved without any drastic changes to the Augustinian paradigm's basic principles. ${ }^{31}$

According to Silva, many theodicies' concepts state that the reason for so much suffering and suffering is that, after completing the world's creation, God returns to heaven and now watches from a distance, without interference in this world. But according to Calvin, God is the Creator and also the "Eternal Governor and Preserver." God did not leave the world to develop by itself. Another Theodicy will claim that the main reason for human suffering is free will and that God has nothing to do

${ }^{29}$ M. L. Peterson, (Ed.), The problem of evil (Second Edi) (Indiana: University of Notre Dame, 2016), 6-7. 2017), 53.

${ }^{30}$ James Kellenberger, God's Goodness and God's Evil (London: Lexington Books,

${ }^{31}$ N. Vorster, "The Augustinian Type of Theodicy: Is It Outdated?" Journal of Reformed Theology 5, no. 1 (2011): 48, https://doi.org/10.1163/156973111X562201. 
with it. However, this view also does not solve the problem of suffering in the world. Calvin believes that as far as humans are concerned, whether they are good or evil, the hearts of Christians will know that their plans, will, efforts, and abilities are under God's hands. ${ }^{32}$

The results of the discussion of the seven concepts of theodicy found that there are positive values that can be taken from the seven views of theodicy that are the answer and have relevance in the context of the COVID-19 pandemic as follows: first, there is suffering from human evil itself, namely moral evil (Leibniz); second, not all problems of suffering can be explained rationally (Bonhoeffer); third, all humans sin, have original sin, thus committing evil (Augustine); fourth, God allows evil and suffering in this world for soul-making to achieve moral maturity (Irenaean); fifth, the secret of life's suffering is part of a journey to make people's souls perfected from time to time (John Hick); sixth, cannot have a proper view of God without finding that He is the source of all goodness. God is omnipotent, and God is good (Calvin); and the seventh, the main solution to suffering is faith, not vision (Lewis).

Apart from differences in the doctrines of each character, the seven values taken from the seven theodicy concepts are by several verses written in the Bible; first, all inclinations of the human heart to do evil (Gen. 6: 5); second, suffering that is difficult to explain rationally (Job 1); third, concerning original sin, one person entered sin, and all have sinned (Rom. 5:12); fourth, misery gives rise to endurance, and perseverance leads to endurance and endurance gives rise to hope (Rom. 5: 3-4); fifth, souls perfected from time to time, Jesus who leads believers in faith to perfection by ignoring the humiliation of enduring the cross (Heb. 12: 2); sixth, God is the source of all goodness, God has a plan of peace and not a plan of accident (Jer. 29:11), seventh, facing suffering with faith, by faith believing that God works in all things (including suffering) to bring good (Rom. 8:28).

\section{Conclusion}

After discussing the results of research on the seven concepts of theodicy above, the authors propose the following arguments: first, to

${ }^{32}$ T. M. Silva, "God and the Meaning of Human Suffering Based on Calvin's Theological Perspective: A Theodicy,” Puritan Reformed Journal 7, no. 2 (2015): 85-86. 
answer the problem of suffering in this world can not only be seen from one side, like the seven concepts of theodicy that have been described, each only looks of one side but needs to see from various points of view. Lewis also says this, the problem of crime does not have a single answer. Just as the Scriptures include narration, poetry, and teaching - all of which are combined to provide a single truth, albeit diverse. Second, because theodicy speaks of God's justice, it cannot be separated from the perspective of the Bible. It is an impossibility to discuss God's justice without seeing or referring to God's words that speak about God's justice and human suffering. Third, the author believes that the word of God must still be a reference or basic foundation to be able to recognize God's justice and human suffering, especially in the context of this COVID-19 pandemic. Fourth, God does not need a defence. Who are human beings who can defend God? The truth is God's word, which states the truth itself, while humans learn to understand what is stated in His word.

\section{Bibliography}

Aubert, A. "Theodicy and the Cross in the Theology of Dietrich Bonhoeffer." Trinity Journal 32, no. 1 (2011): 47-67.

Brooks, P., \& Neal, D. A. The Lexham Bible Dictionary (J. D. Barry, D. Bomar, D. R. Brown, D. Klippenstein, D. Mangum, \& C. Sinclair Wolcott, Eds.). Bellingham, WA: Lexham Press, 2016.

Byerly, T. R. "Free Will Theodicies for Theological Determinists." Sophia 56, no. 2 (2017): 289-310. https://doi.org/10.1007/sll841-016-0563-8. Camposampiero, M. F., Geretto, M., \& Perissinotto, L. Theodicy and Reason Logic, Metaphysics, and Theology in Leibniz's Essais de Theodicee (1710).

Venesia: Digital Publishing, 2016.

Cheetham, David. John Hick: A Critical Introduction and Reflection. New York: Routledge, 2017.

Cross, F. L., and E. A. Livingstone, eds. The Oxford Dictionary of the Christian Church. The Oxford Dictionary of the Christian Church. Oxford University Press, 2009.

https://www.oxfordreference.com/view/10.1093/acref/97801928029 03.001.0001/acref-9780192802903.

du Rand, J. A. "The Mystery in Theodicy." Neotestamentica 50, no. 3 (2016): 167-186. https://doi.org/10.1353/neo.2016.0023.

Haig, A. R. "Dying and Living with Christ: A Sketch of a Participatory 
Theory of the Atonement Founded in Platonic Realism and an Irenaean "soul-making" Theodicy." Colloquium: The Australian and New Zealand Theological Review 51, no. 1 (2019): 81-100. https:/hcommons.org/deposits/item/hc:27869/.

Kellenberger, James. God's Goodness and God's Evil. London: Lexington Books, 2017.

Leibniz, F. von G. W. THEODICY: Essays on the Goodness of God, the Freedom of Man, and the Origin of Evil (Austin Farrer, Ed.). Oxford: Bibliobazaar, 2007.

Louw, D. J. "The aesthetics of Covid-19 within the pandemic of the corona crisis. from loss and grief to silence and simplicity-a philosophical and pastoral approach." Acta theol. 40, no. 2 (2020): 125-149. http://dx.doi.org/10.18820/23099089/actat.v40i2.08.

Mangum, D. The Lexham Glossary of Theology. Bellingham, WA: Lexham Press, 2014.

McGraw, E. "Peace, child; you don't understand: Theodicy in the writings of C. S. Lewis." The Westminster Theological Journal 80, no. 1 (2018): 51-76.

Miller, T. E. "Reformed Theodicy: Calvin's View of the Problem of Evil." Prj, 10 (2018): 119-139. Retrieved from http://www.reformed.org/documents/calvin/calvin_predest_3.html. Peterson, M. L. (Ed.). The problem of evil (Second Edi). Indiana: University of Notre Dame, 2016.

"Q\&A on coronaviruses (COVID-19)." World Health Organization. pp. 1-2. Retrieved from https://www.who.int/emergencies/diseases/novelcoronavirus-2019/question-and-answers-hub/q-a-detail/q-acoronaviruses.

Rateau, Paul. Leibniz on the Problem of Evil. New York: Oxford UniversityPress, 2019.

Scott, M. S. M. Pathways in Theodicy: An Introduction to the Problem of Evil. Minneapolis: Fortress, 2015.

Silva, T. M. "God and the Meaning of Human Suffering Based on Calvin's Theological Perspective: A Theodicy." Puritan Reformed Journal 7, no. 2 (2015): 79-94.

T. Editors of Encyclopaedia Britannica. "Best of all possible worlds." Encyclopedia Britannica, June 6, 2017.

https://www.britannica.com/topic/best-of-all-possible-worlds.

Vorster, N. "The Augustinian Type of Theodicy: Is It Outdated?" Journal of Reformed Theology 5, no. 1 (2011): 26-48. https://doi.org/10.1163/156973111X562201. 